\title{
PEMBUATAN DAN KARAKTERISASI KARBON AKTIF DARI KULIT PISANG KEPOK (Musa paradisiaca L.) SEBAGAI ADSORBEN SENYAWA POLISIKLIK AROMATIK HIDROKARBON FENANTRENA
}

\author{
Riri Auliya ${ }^{1}$, Ni Luh Gede Ratna Juliasih ${ }^{1}$, Rinawati ${ }^{*}$ \\ ${ }^{1}$ Jurusan Kimia, Universitas Lampung \\ rinawati@fmipa.unila.ac.id
}

Artikel Info
Diterima tanggal
08.06 .2018
Disetujui
publikasi tanggal
30.10.2018
Kata kunci :
fenantrena,
isotherm
Freundlich,
karbon aktif,
PAH

\begin{abstract}
ABSTRAK
Polisiklik aromatik hidrokarbon (PAH) merupakan kelompok organik polutan yang mempunyai dampak serius pada lingkungan karena sifatnya yang toksik, karsinogenik, dan mutagenik. Dalam penelitian ini telah dilakukan uji adsorpsi dengan menggunakan adsorben karbon aktif dari kulit pisang yang sudah diaktivasi menggunakan $\mathrm{ZnCl}_{2}$ 30\% dengan rasio impregnasi 3:3. Karakterisasi karbon aktif dilakukan dengan menggunakan SEM untuk mengetahui morfologi permukaan serta digunakan spektrofotometer FT-IR untuk mengidentifikasi gugus fungsi. Uji adsorpsi dilakukan dengan metode batch untuk menentukan kadar optimum adsorben, waktu kontak, dan konsentrasi adsorbat menggunakan spektrofotometer UV-VIS pada panjang gelombang $250 \mathrm{~nm}$. Hasil optimasi adsorpsi PAH dengan menggunakan fenantrena diperoleh pada konsentrasi $3 \mathrm{ppm}$, pada penambahan kadar adsorben $25 \mathrm{mg}$ dan waktu optimum 60 menit. Data kinetika adsorpsi fenantrena cenderung mengikuti model kinetika pseudo orde dua dengan nilai koefisien korelasi R2 sebesar 0,9914, sedangkan data isoterm adsorpsi fenantrena mengikuti model isoterm Freundlich dengan nilai koefisien korelasi sebesar 0,7863.
\end{abstract}

\begin{abstract}
Polycyclic Aromatic Hydrocarbon (PAH) is organic pollutant that have a serious impact on the environment due to their toxic, carcinogenic and mutagenic properties. one of which can be caused by Polycyclic Aromatic Hydrocarbon compounds (PAH) type of phenanthrene. In this research, adsorption has been conducted using activated carbon adsorbent from banana peels that are activated using $\mathrm{ZnCl}_{2}$ $30 \%$ with impregnation ratio of 3:3. Characterization of activated carbon was performed using SEM to observe morfphology morphology surface and FT-IR spectrophotometer to identify the functional group. Adsorption test was conducted by the batch method to determine the optimum of adsorben doset, contact time, and the concentration of adsorbat using UV-VIS spectrophotometer at a wavelength of $250 \mathrm{~nm}$. The result shows that the optimum of adsorption concentration of $3 \mathrm{ppm}$ adsorbent levels of $25 \mathrm{mg}$ and reached for 60 minutes. Phenanthrene adsorption kinetics data tend to follow the kinetics of pseudoorder with correlation coefficients $\left(R^{2}\right)$ of 0.9914, while phenanthrene adsorption isotherme data was to tend modeled isotherme Freundlich coefficient of correlation 0.7863.
\end{abstract}

\section{PENDAHULUAN}

Perindustrian di dunia sejak beberapa dekade telah berkembang pesat. Namun seiring dengan perkembngan tersebut, potensi terjadinya pencemaran semakin besar pula lingkungan. Material pencemaran lingkungan diantaranya karbon monoksida (CO), nitrogen oksida (NOx), 
Particulate Matter (PM), hidrokarbon (HC), dan juga polutan yang tidak umum seperti semivolatile organic compound dan Polisiklik Aromatik Hidrokarbon (PAH) (Pongpiachan, et al., 2012). PAH adalah suatu polutan yang sangat berbahaya bagi kesehatan.

Proses pembakaran yang kurang sempurna terhadap senyawa organik dapat menghasilkan senyawa PAH. PAH menjadi salah satu pencemar prioritas European Union (EU) dan Environmental Protection Agency (EPA) karena bersifat mutagenik, karsinogenik, dan teratogenik (Sverdrup, et al., 2006; Qiao, et al., 2006). Penelitian yang telah dilakukan oleh Gamboa pada tahun 2008 menunjukkan bahwa komponen senyawa PAH dapat menyebabkan kerusakan pada sel limfosit manusia. PAH dengan berat molekul rendah umumnya memiliki 23 cincin aromatik dalam satu hidrokarbon, seperti fenantrena, naftalena, asenaftena, flourena dan antrasena (Sverdrup, et al., 2006; Qiao, et al., 2006). Sifatnya yang membahayakan tersebut maka sangatlah penting untuk menghilangkan atau meminimalisasi keberadaan senyawa tersebut.

Metode yang tepat untuk mengolah limbah yang mengandung senyawa PAH khususnya senyawa fenantrena adalah melalui proses adsorpsi. Proses adsorpsi diharapkan dapat menurunkan atau bahkan menghilangkan konsentrasi senyawa fenantrena yang berbahaya bagi lingkungan. Proses ini melibatkan interaksi antara adsorbat dan adsorben. Beberapa contoh adsorben (zat penjerap) yang dapat digunakan pada proses adsorpsi adalah silika gel, alumina aktif, zeolit, polimer, dan karbon aktif (Wang dan Kaskel, 2012). Adsorben berupa karbon aktif dapat diperoleh dari limbah organik yang mengandung karbon seperti sekam padi, ampas tebu, tempurung kelapa, kulit pisang dan lain sebagainya (Wang dan Kaskel, 2012).

Pisang merupakan salah satu tanaman yang banyak dihasilkan di Indonesia. Lampung dapat memproduksi 677.781 ton tahun 2011, 687.761 ton tahun 2012 dan 817.606 tahun 2013 (BPS, 2014). Kulit pisang masih jarang sekali dimanfaatkan, hanya sesekali digunakan sebagai pakan ternak dan bisa dijadikan teknologi penjernihan air selebihnya dibiarkan menumpuk dan membusuk menjadi limbah yang dapat menyebabkan pencemaran lingkungan dan sumber penyakit apabila dibiarkan begitu saja.

Beberapa penelitian yang telah dilakukan sebelumnya melaporkan penggunaan kulit pisang sebagai karbon aktif yang dapat menurunkan kandungan suatu senyawa seperti $\mathrm{Cu}^{2+}$, $\mathrm{Ni}^{2+}, \mathrm{Pb}^{2+}$ (Tran, et al., 2016), dan bahan pewarna (Khalfaoui, et al., 2012). Kulit pisang 
memiliki komposisi kimia berupa selulosa, hemiselulosa, pigmen klorofil dan zat pektin yang mengandung asam galacturonic, arabinosa, galaktosa dan rhamnosa yang merupakan senyawa organik dan memiliki potensi cukup besar untuk dijadikan sebagai penyerap berupa karbon aktif.

Berdasarkan uraian di atas maka dalam penelitian ini telah dilakukan pembuatan karbon aktif dari kulit pisang untuk mengetahui kemampuan adsorpsinya terhadap senyawa PAH yaitu fenantrena. Karakterisasi dilakukan menggunakan Scanning Electron Microscope (SEM), Fourier Transform Infrared Spectroscopy (FT-IR) dan Particle Size Analyzer (PSA), serta untuk mengetahui jumlah yang teradsorpsi akan dilakukan menggunakan spektrofotometer UV-VIS.

\section{METODE}

\section{Alat dan Bahan}

Bahan-bahan yang digunakan yaitu kulit pisang, $\mathrm{ZnCl}_{2}(5,10,30,40,60,70 \%), \mathrm{NaCl}(5,10$, $30 \%$ ), $\mathrm{HCl}$ 0,2 N, Metanol (HPLC grade), aquabides, air suling dan larutan standar fenantrena, larutan iodium $0,1 \mathrm{~N}$, larutan natrium thiosulfat $0,1 \mathrm{~N}$, dan amilum $1 \%$. Alat-alat yang digunakan yaitu peralatan gelas, mortar dan alu, $\mathrm{pH}$ meter, shaker, kertas saring biasa, oven, furnace, neraca analitik, ayakan $106 \mu \mathrm{m}$, desikator, centrifuge, Scanning Electron Microscope (SEM), Particle Size Analyzer (PSA), Fourier Transform Infra Red (FTIR), dan Spektrofotometer Ultra Violet-Visible (UV-VIS).

\section{Prosedur}

\section{Pembuatan Karbon Aktif}

Kulit pisang yang telah bersih dikeringkan dibawah sinar matahari selama 3 hari, dilanjutkan dengan pengovenan pada suhu $110^{\circ} \mathrm{C}$ sampai berat konstan. Kemudian dikarbonisasi dalam furnace pada suhu $500^{\circ} \mathrm{C}$ selama 1 jam, hasil karbonisasi dihaluskan. Selanjutnya dilakukian aktivasi kimia dengan aktivator $\mathrm{ZnCl}_{2}(5,10,30,40,60$, dan 70\%) dan $\mathrm{NaCl}(5,10$, dan 30\%), dilanjutkan dengan aktivasi fisika dalam furnace pada suhu $700^{\circ} \mathrm{C}$ selama 1 jam. Karbon yang telah aktif dicuci dengan $\mathrm{HCl}$ 0,2 $\mathrm{N}$ dan akuades sampai $\mathrm{pH}$ netral, lalu dihaluskan dan diayak. Kemudian dilakukan uji identifikasi karakteristik karbon aktif sesuai SNI 06-3730-1995. Selanjutnya dengan prosedur yang sama divariasikan perbandingan karbon aktif dengan aktivator, 
menggunakan konsentrasi optimum yang telah diperoleh dengan variasi impregnasi 1:5, 2:4, $3: 3,4: 2$, dan $5: 1$.

\section{Karakterisasi}

Karbon aktif kulit pisang yang diperoleh dikarakterisasi menggunakan SEM untuk melihat morfologi permukaan dari karbon aktif. Selain itu, karbon aktif kulit pisang juga dikarakterisasi menggunakan PSA untuk mengetahui distribusi ukuran partikel dan menggunakan FT-IR untuk menentukan gugus fungsi.

\section{Uji Adsorpsi}

\section{Penentuan Massa Optimum Adsorben}

Sebanyak $20 \mathrm{~mL}$ larutan fenantrena 3 ppm ditambahkan adsorben dengan variasi massa 5, 10, 15, 20, 25, 30, dan $35 \mathrm{mg}$. Campuran tersebut diaduk menggunakan shaker selama 1 jam pada kecepatan $150 \mathrm{rpm}$. Kemudian larutan disentrifugasi dengan kecepatan $2000 \mathrm{rpm}$ selama 10 menit. Filtrat yang dihasilkan dianalisis dengan spektrofotometer UV-Vis untuk mengetahui konsentrasi larutan standar fenantrena yang teradsorpsi.

\section{Penentuan Waktu Kontak Optimum (Laju Adsorpsi)}

Sebanyak $20 \mathrm{~mL}$ larutan fenantrena 3 ppm ditambahkan massa adsorben optimum. Campuran tersebut diaduk menggunakan shaker dengan variasi waktu 10, 30, 60, 90 dan 120 menit pada kecepatan $150 \mathrm{rpm}$. Selanjutnya, larutan disentrifugasi dengan kecepatan $2000 \mathrm{rpm}$ selama 10 menit. Filtrat yang dihasilkan dianalisis dengan spektrofotometer UV-Vis untuk mengetahui konsentrasi larutan standar fenantrena yang teradsorpsi.

\section{Penentuan Konsentrasi Larutan Standar Fenantrena Optimum}

Sebanyak $20 \mathrm{~mL}$ larutan fenantrena dengan variasi konsentrasi 1, 3, 5, 7, dan 9 ppm masingmasing ditambah adsorben dengan massa optimum. Campuran tersebut diaduk dengan waktu kontak optimum pada kecepatan $150 \mathrm{rpm}$. Kemudian larutan disentrifugasi dengan kecepatan 2000 rpm selama 10 menit. Filtrat yang dihasilkan dianalisis dengan spektrofotometer UV-Vis untuk mengetahui konsentrasi larutan standar fenantrena yang teradsorpsi. 


\section{HASIL DAN PEMBAHASAN}

\section{Identifikasi Karakteristik Karbon Aktif}

Uji karakteristik yang telah dilakukan berdasarkan SNI 06-3730-1995, dari beberapa variasi yang telah dilakukan uji identifikasi karakteristik lainnya, dapat diketahui kondisi optimum dari masing-masing aktivator yang dapat dilihat pada Tabel 1, yaitu pada aktivator $\mathrm{ZnCl}_{2} 30 \%$ dengan rasio impregnasi 3:3 dan $\mathrm{NaCl}$ 10\% dengan rasio impregnasi 3:3.

Tabel 1. Hasil optimum identifikasi karakteristik karbon aktif

\begin{tabular}{ccccc}
\hline Identifikasi & $\mathrm{ZnCl}_{2}$ & $\mathrm{NaCl} \mathrm{Optimum}$ & SNI 06- \\
Karakteristik & $\begin{array}{c}\text { Optimum 30\% } \\
10 \%\end{array}$ & $\begin{array}{c}\text { Kesesuaian } \\
\text { dengan }\end{array}$ \\
& $3: 3(\%)$ & $3: 3(\%)$ & $(\%)$ & SNI 06- \\
& & & & $3730-1995$ \\
\hline Rendemen & 49,970 & 48,765 & - & - \\
Kadar Air & 10,294 & 12,635 & Maks 15 & Memenuhi \\
Kadar Zat & 20,6752 & 23,0567 & Maks 25 & Memenuhi \\
Terbang & 5,6453 & 8,0789 & Maks 10 & Memenuhi \\
Kadar Abu & 73,6795 & 68,8644 & - & - \\
Karbon Aktif & & & & Min 750 \\
Murni & 580,64 & 482,22 & & Tidak \\
Adsorpsi Iod & & & & Memenuhi \\
\hline
\end{tabular}

Berdasarkan syarat mutu karbon aktif pada SNI 06-3730-1995, dapat diketahui bahwa kadar air, kadar abu, dan kadar zat terbang pada tabel diatas memenuhi kesesuaian, sedangkan adsorpsi iod berada dibawah syarat mutu karbon aktif pada $\mathrm{ZnCl}_{2}$ sebesar $580,64 \%$ dan pada $\mathrm{NaCl}$ sebesar $482,22 \%$, hal ini juga terjadi pada penelitian yang telah dilakukan oleh (Abdi dkk, 2015) dimana uji adsorpsi menggunakan karbon aktif dari kulit pisang kepok tidak mememenuhi kesesuaian dengan SNI 06-3730-1995. Belum terpenuhinya daya adsorpsi iod minimum diperkirakan akibat ketidaksesuaian aktivator yang dipakai dan ketidakstabilan senyawa yang diadsorpsi. Pada penelitian ini aktivator dengan daya serap terhadap iodium yang mendekati kesesuain terhadap SNI 06-3730-1995, yaitu $\mathrm{ZnCl}_{2}$ 30\% dengan rasio impregnasi 3:3.

\section{Karakterisasi Adsorben}

Karakterisasi dengan SEM 
Analisis morfologi permukaan adsorben dilakukan dengan menggunakan SEM. Hasil analisis yang diperoleh dapat dilihat adanya perbedaan struktur permukaan antara karbon tanpa aktivasi, tanpa aktivasi, karbon aktif dengan aktivator $\mathrm{NaCl}$, dan karbon aktif dengan aktivator $\mathrm{ZnCl}_{2}$ seperti terlihat pada Gambar 1.
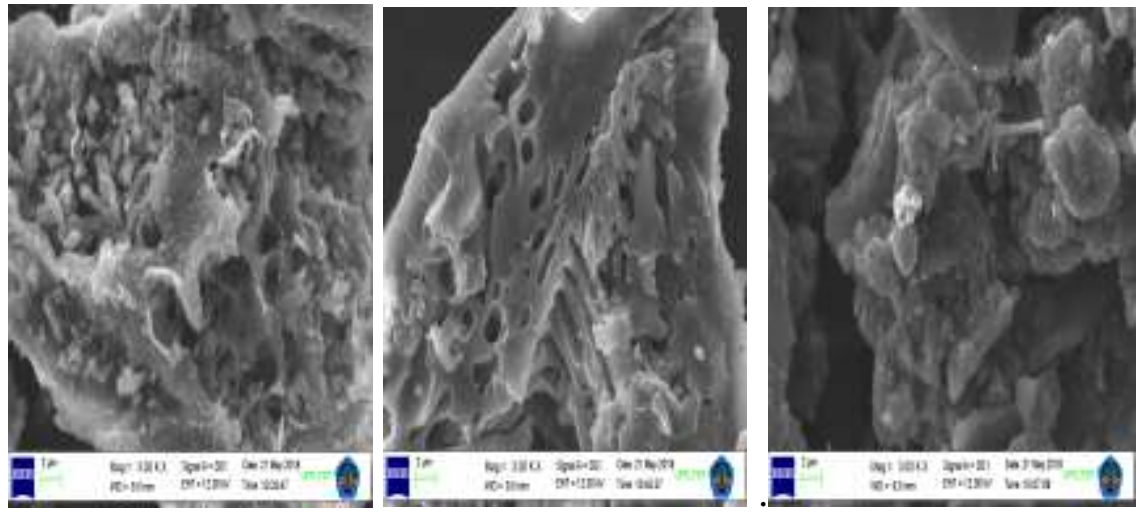

Gambar 1. Hasil SEM dengan perbesaran 3.000x pada permukaan adsorben berupa (a) karbon tanpa aktivasi, (b) karbon aktif teraktivasi $\mathrm{ZnCl}_{2}$, (c) karbon aktif teraktivasi $\mathrm{NaCl}$.

Dari Gambar 1 dapat diketahui bahwa pori-pori karbon teraktivasi $\mathrm{ZnCl}_{2}$ memiliki pori-pori paling baik diantara karbon tanpa aktivasi dan teraktivasi $\mathrm{NaCl}$. Hal ini dikarenakan pori-pori yang terdapat pada karbon tanpa aktivasi masih tertutupi oleh pengotor akibat proses karbonisasi menggunakan furnace, sedangkan pada karbon teraktivasi $\mathrm{NaCl}$ diakibatkan karena selama proses pemanasan menggunakan furnace, $\mathrm{NaCl}$ tidak terdekomposisi secara sempurna, sehingga ruangan yang terisi olehnya tidak terbuka secara sempurna.

\section{Karakterisasi dengan PSA}

Analisis untuk mengetahui distribusi ukuran partikel dengan menggunakan PSA. Hasil analisis yang diperoleh dapat dilihat pada Gambar 2. 

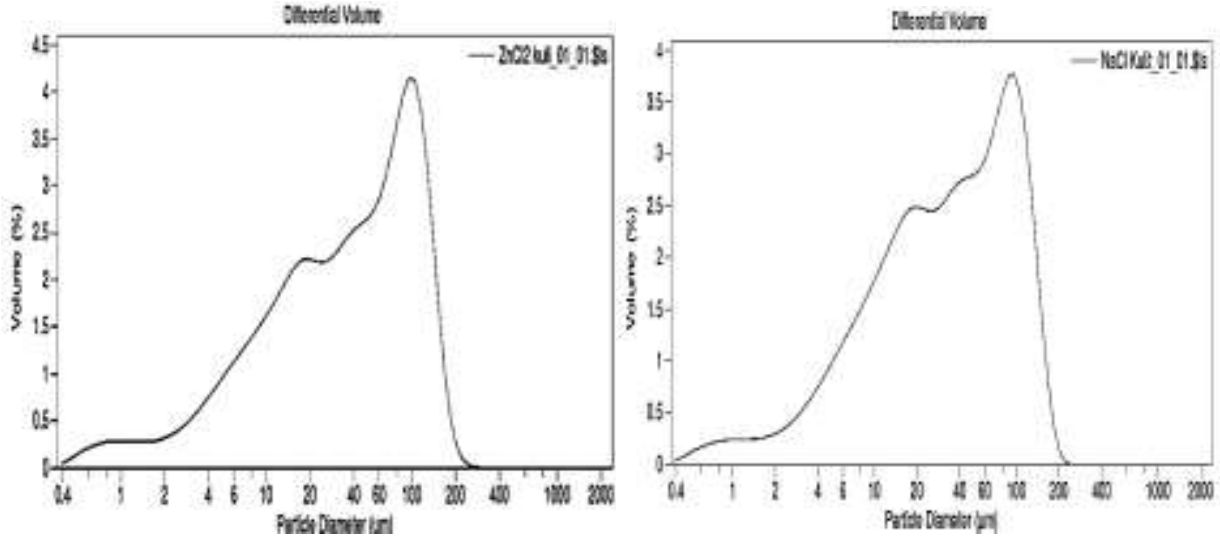

Gambar 2. (a) Grafik distribusi ukuran partikel karbon aktif dengan aktivator $\mathrm{ZnCl}_{2}$, (b) Grafik distribusi ukuran partikel karbon aktif dengan aktivator $\mathrm{NaCl}$.

Tabel 2. Distribusi ukuran partikel dengan aktivator $\mathrm{ZnCl}_{2}$

\begin{tabular}{cc}
\hline Ukuran Partikel $(\mu \mathrm{m})$ & Volume $(\%)$ \\
\hline $0,4-2$ & 5,301 \\
$3-10$ & 15,390 \\
$11-60$ & 43,740 \\
$61-285$ & 35,549 \\
\hline
\end{tabular}

Tabel 3. Distribusi ukuran partikel dengan aktivator $\mathrm{NaCl}$

\begin{tabular}{cc}
\hline Ukuran Partikel $(\mu \mathrm{m})$ & Volume $(\%)$ \\
\hline $0,4-2$ & 5,524 \\
$3-10$ & 15,190 \\
$11-60$ & 47,690 \\
$61-235$ & 31,610 \\
\hline
\end{tabular}

Dari gambar 2, tabel 2 dan 3 diatas dapat diketahui bahwa karbon aktif dengan aktivator $\mathrm{ZnCl}_{2}$ memiliki kelimpahan tertinggi pada distribusi ukuran partikel 11-60 $\mu \mathrm{m}$ sebanyak 43,740\%, karbon aktif dengan aktivator $\mathrm{NaCl}$ juga memiliki kelimpahan tertinggi yang sama pada distribusi ukuran partikel 11-60 $\mu \mathrm{m}$ sebanyak 47,690\%, setara dengan ukuran partikel $11 \times 10^{4}-$ $60 \times 10^{4}$ dalam satuan Angstrom. Oleh karena itu, karbon aktif dari kulit pisang ini termasuk kedalam karbon aktif powder dengan ukuran makropori, karena berada pada ukuran diameter lebih besar dari $250 \mathrm{~A}^{\circ}$ (Beukens, et al., 1985). 

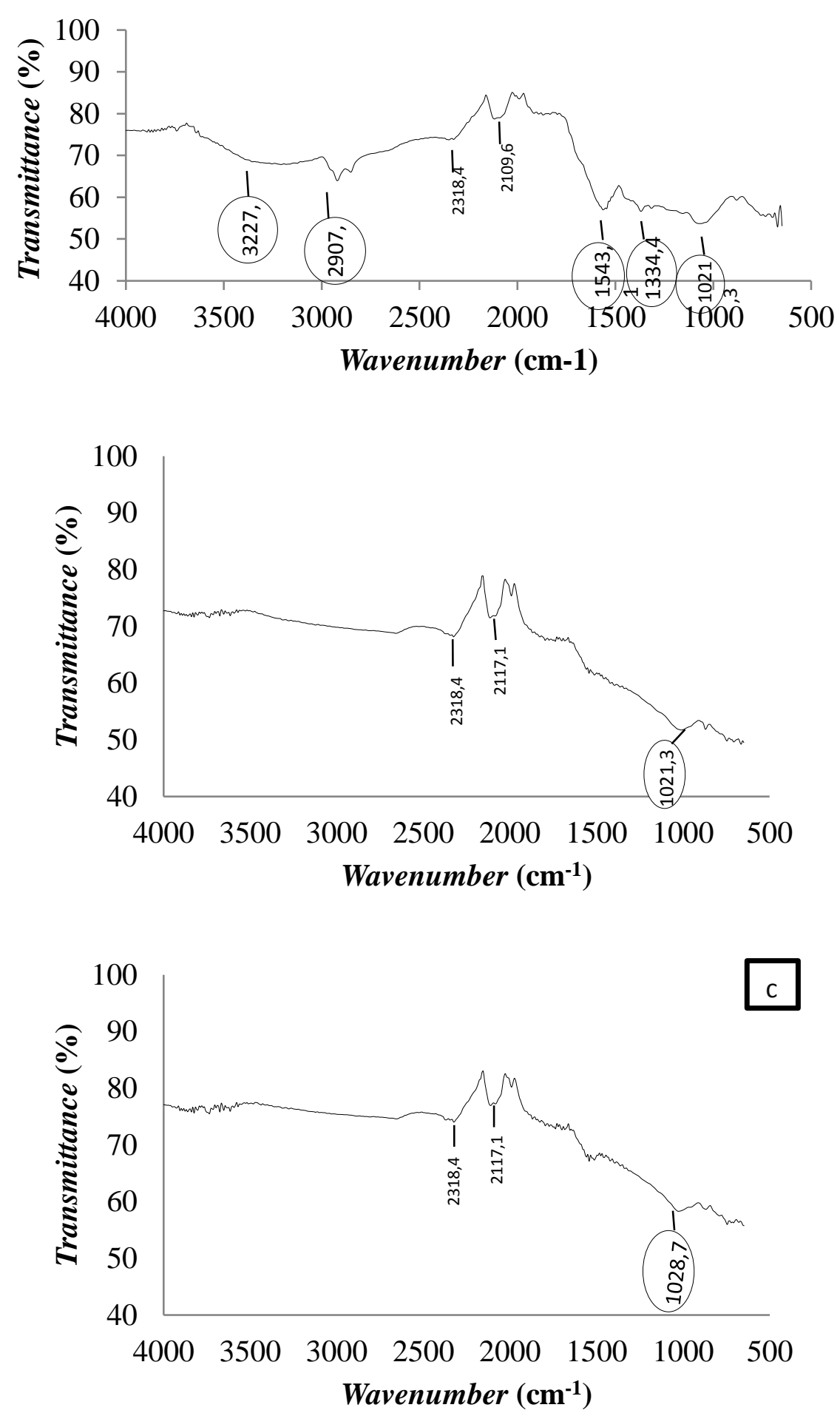

Gambar 3. (a) Spektrum FT-IR tak teraktivasi, (b) Spektrum FT-IR teraktivasi $\mathrm{NaCl}$, (c) Spektrum FT-IR teraktivasi $\mathrm{ZnCl}_{2}$. 


\section{Karakterisasi dengan FTIR}

Analisis gugus fungsi pada karbon aktif dilakukan dengan menggunakan FT-IR. Dari hasil analisis dapat dilihat pada Gambar 3.

Tabel 4. Gugus fungsi pada hasil IR karbon tanpa aktivasi

\begin{tabular}{ccc}
\hline $\begin{array}{c}\text { Bilangan Gelombang } \\
\left(\mathbf{c m}^{-\mathbf{1}}\right)\end{array}$ & Pita Serapan & Gugus Fungsi \\
\hline 3227,9 & Vibrasi Ulur & $-\mathrm{OH}$ \\
2907,3 & Vibrasi Ulur & $\mathrm{C}-\mathrm{H}$ alkana \\
1543,1 & Vibrasi Tekuk & $\mathrm{C}=\mathrm{C}$ \\
1334,4 & Vibrasi Tekuk & $-\mathrm{OH}$ \\
1021,3 & Vibrasi Ulur & $\mathrm{C}-\mathrm{O}$ \\
2318,4 & Vibrasi Ulur & $-\mathrm{NH}$ \\
2109,6 & Vibrasi Ulur & $\mathrm{C} \equiv \mathrm{N}$ \\
\hline
\end{tabular}

Dari Gambar 3 dan Tabel 4 antara karbon tak teraktivasi dengan karbon teraktivasi $\mathrm{NaCl}$ (Gambar 3 b) dan karbon teraktivasi $\mathrm{ZnCl}_{2}($ Gambar $3 \mathrm{c}$ ) terlihat adanya perbedaan yang mencolok. Aktivasi mempengaruhi gugus fungsi yang ada, pada kedua karbon teraktivasi hanya tersisa puncak vibrasi ulur gugus gugus - $\mathrm{NH}$ pada bilangan gelombang $2318,4 \mathrm{~cm}^{-1}$, serta adanya pergeseran vibrasi ulur gugus $C \equiv N$ pada bilangan gelombang $2109,6 \mathrm{~cm}^{-1}$ menjadi $2117,1 \mathrm{~cm}^{-1}$; sedangkan pada karbon teraktivasi $\mathrm{ZnCl}_{2}$ juga mengalami pergeseran vibrasi ulur gugus $\mathrm{C}-\mathrm{O}$ pada bilangan gelombang $1021,3 \mathrm{~cm}^{-1}$ menjadi $1028,7 \mathrm{~cm}^{-1}$.

\section{Uji Adsorpsi}

\section{Penentuan Massa Optimum Adsorben}

Hasil adsorpsi senyawa fenantrena oleh karbon aktif ditampilkan pada Gambar 4. Jumlah fenantrena yang terserap meningkat ketika massa adsorben yang ditambahkan berkisar 5-25 mg pada konsentrasi larutan standar fenantrena yang tetap, akan tetapi ketika massa adsorben yang digunakan menjadi 30-35 mg, jumlah fenantrena yang terserap mengalami penurunan. Hal ini disebabkan karena pada massa adsorben yang lebih besar, terjadi penutupan pori-pori pada adsorben yang sudah mulai jenuh sehingga kemampuan adsorpsi menurun. 


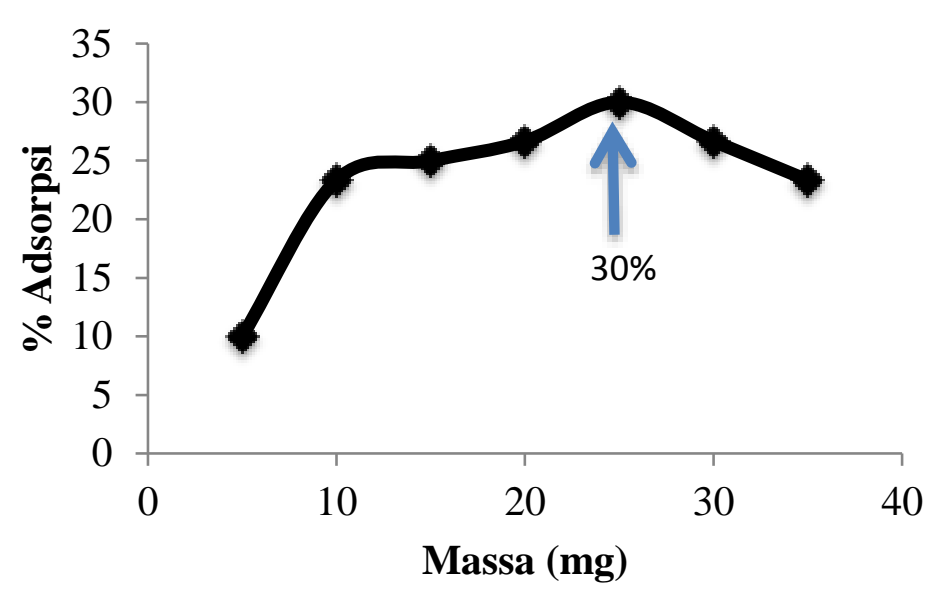

Gambar 4. Kurva variasi massa adsorben pada proses adsorpsi fenantrena.

\section{Penentuan Waktu Kontak Optimum (Laju Adsorpsi)}

Hasil adsorpsi fenantrena oleh karbon aktif yang didasarkan pada waktu kontak disajikan pada Gambar 5. Dari Gambar 21 dapat dilihat bahwa jumlah fenantrena yang teradsorpsi terhadap waktu interaksi mengalami peningkatan mulai 10 menit pertama hingga mencapai waktu optimum 60 menit dengan persen adsorpsi sebesar 36,67\%, sedangkan pada waktu 90 menit dan 120 menit adsorpsi mengalami penurunan yang disebabkan oleh pori-pori adsorben karbon aktif menjadi jenuh yang dapat mengakibatkan fenantrena akan terdesorpsi kembali.

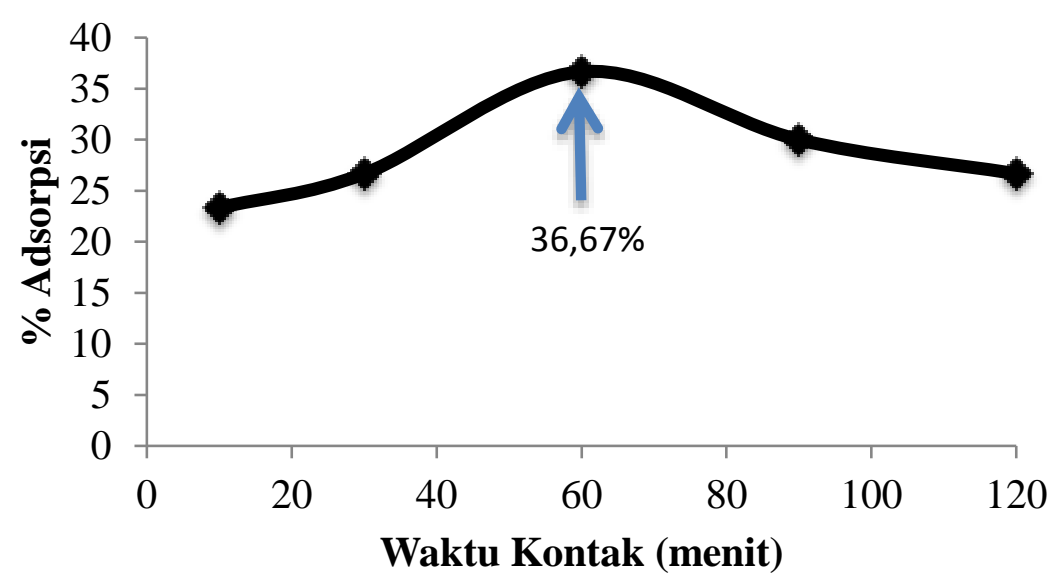

Gambar 5. Kurva variasi waktu kontak pada proses adsorpsi fenantrena.

Data yang terdapat pada Gambar 5 dianalisis menggunakan persamaan pseudo orde satu dan orde dua. Berdasarkan hasil kinetika persamaan pseudo orde satu untuk adsorben karbon aktif 
tidak dapat diperoleh kurva kinetika dikarenakan tidak dapat memenuhi persamaan orde satu. Selanjutnya hasil analisis berdasarkan kinetika persamaan pseudo orde dua untuk karbon aktif dapat dilihat pada Gambar 6.

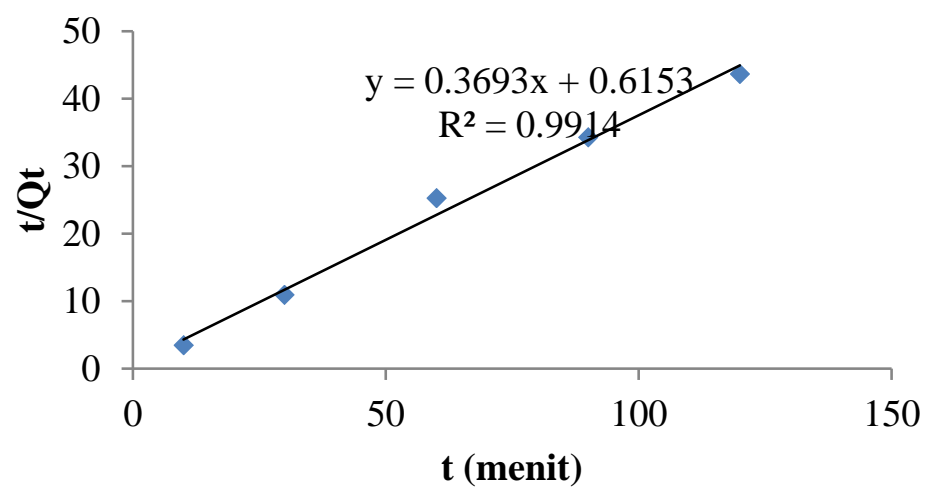

Gambar 6. Kurva kinetika pseudo orde dua pada karbon aktif terhadap fenantrena.

Berdasarkan hasil analisis adsorben karbon aktif pada Gambar 6 dengan menggunakan persamaan pseudo orde dua menghasilkan nilai konstanta laju pseudo orde dua $\left(\mathrm{k}_{2}\right)$ pada adsorben terhadap fenantrena sebesar $0,80258 \mathrm{~g} \mathrm{mmol}^{-1}$ menit $^{-1}$ dengan nilai koefisien korelasi $\left(\mathrm{R}^{2}\right)$ sebesar 0,9914 cenderung mendekati 1, sehingga dapat disimpulkan bahwa proses adsorpsi dalam penelitian ini mengikuti kinetika pseudo orde dua.

\section{Penentuan Konsentrasi Larutan Standar Fenantrena Optimum}

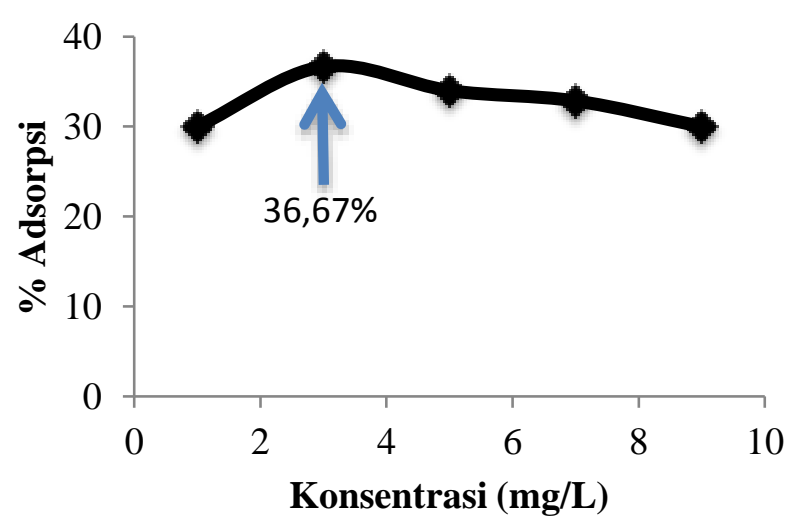

Gambar 6. Kurva variasi konsentrasi fenantrena oleh adsorben karbon aktif. 
Hasil adsorpsi fenantrena oleh karbon aktif yang didasarkan pada konsentrasi larutan fenantrena disajikan pada Gambar 6, menunjukkan bahwa batas optimum pada konsentrasi 3 ppm, yang memperoleh data peningkatan adsorpsi dengan persen adsorpsi sebesar 36,67\%, sehingga sisi aktif dari karbon aktif sudah terpenuhi oleh fenantrena yang berlebih. Data yang tersaji pada Gambar 6 selanjutnya dianalisis dengan menggunakan model isoterm adsorpsi.
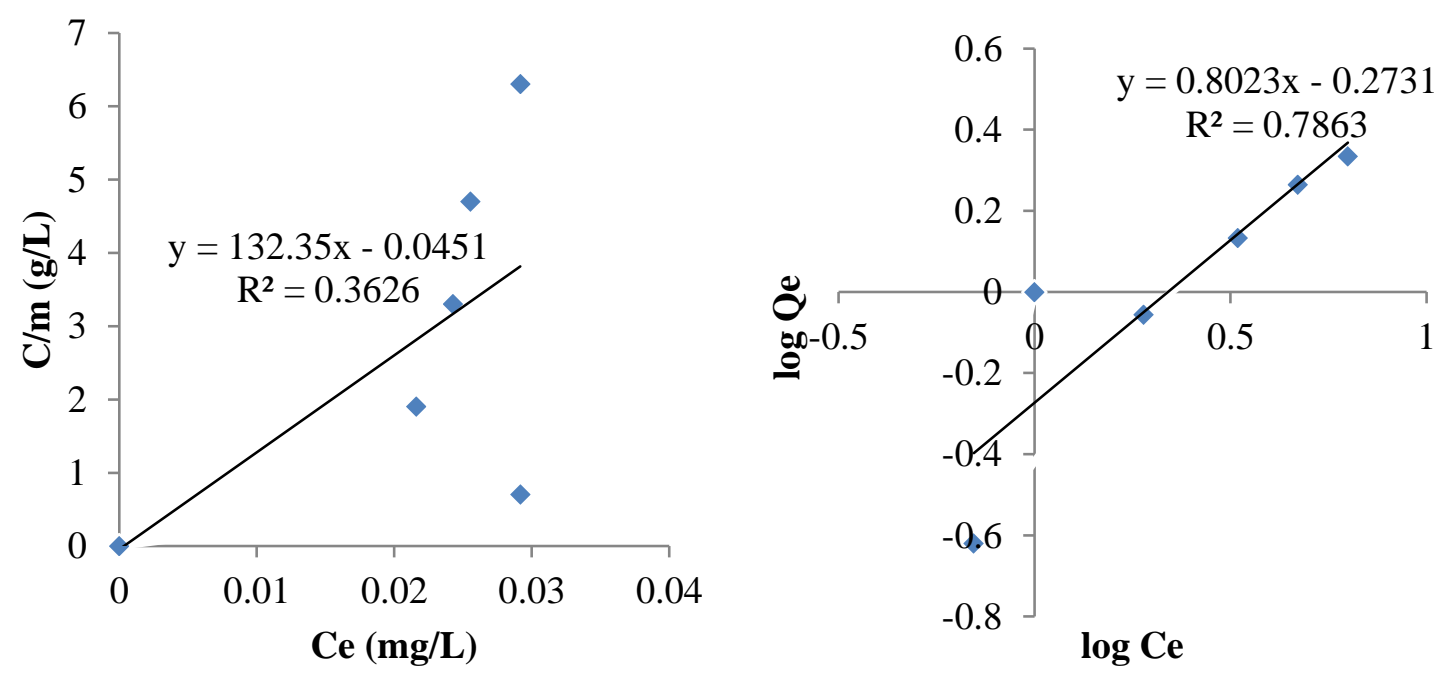

Gambar 7. Kurva isoterm adsorpsi menurut (a) model Langmuir, dan (b) model Freundlich pada fenantrena oleh karbon aktif.

Berdasarkan data yang tersaji dalam Gambar 7 dapat diamati bahwa pola isoterm adsorpsi fenantrena pada adsorben karbon aktif cenderung mengikuti isoterm adsorpsi Freundlich. Hal ini ditunjukkan dengan nilai koefisien korelasi $\left(\mathrm{R}^{2}\right)$ pada parameter isoterm Freundlich sebesar 0,7863 dan lebih besar dibandingkan dengan isoterm Langmuir sebesar 0,3626, sehingga adsorpsi terjadi secara fisika. Adsorpsi fisika terjadi karena adanya gaya van der Waals, hal ini menunjukkan bahwa molekul-molekul yang diadsorpsi terjadi secara fisika dan adsorbat tidak terikat kuat pada permukaan. Selain itu adsorbat akan mengalami proses balik yang cepat, sehingga mudah diganti dengan molekul lain (Yansya, 2013).

\section{KESIMPULAN}

Pembuatan karbon aktif dari kulit pisang telah berhasil dilakukan dengan kemampuan adsorpsi tertinggi pada karbon aktif teraktivasi $\mathrm{ZnCl}_{2} 30 \%$ dengan rasio impregnasi 3:3 dibuktikan dengan hasil terbaik diantara variasi lain, hal ini dibuktikan dengan hasil 
identifikasi karakteristik SNI 06-3730-1995, karakterisasi SEM, dan karakterisasi menggunakan PSA. Adsorpsi fenantrena oleh adsorben karbon aktif optimum pada massa 25 mg dengan waktu kontak selama 60 menit, menggunakan konsentrasi 3 ppm, sehingga diperoleh adsorpsi sebesar 36,67\%. Laju adsorpsi fenantrena mengikuti kinetika kimia pseudo orde dua dengan nilai koefisien korelasi $\left(\mathrm{R}^{2}\right)$ sebesar 0,9914 . Isoterm adsorpsi fenantrena oleh adsorben karbon aktif pada penelitian ini mengikuti model isoterm Freundlich dengan nilai koefisien korelasi $\left(\mathrm{R}^{2}\right)$ sebesar 0,7863 .

\section{DAFTAR PUSTAKA}

Abdi, C., R. M. Khair, dan M. W. Saputra. 2015. Pemanfaatan Limbah Kulit Pisang Kepok (Musa acuminate L.) sebagai Karbon Aktif untuk Pengolahan Air Sumur Kota Banjarbaru: Fe dan Mn. Jurnal Teknik Lingkungan. 1(1): 8-15.

Badan Pusat Statistik. 2014. Produksi Tanaman Hortikultura Provinsi Lampung. Badan Pusat Statistik Provinsi Lampung. Bandar Lampung.

Beukens, A., H. Keirsse,J. Schoeters and A. Verbeeck. 1985. Production of Activated Carbon from Euphorbia Tiraculli. University of Chicago Press. Brussel.

Khalfaoui, A., A. H. Meniai, and K. Derbal. 2012. Isotherm and Kinetics Study of Biosorption of Cationic Dye onto Banana Peel. Energy Procedia. 19:286-295.

Sverdrup, N. L.E., and P.H. Krogh. 2006. Soil Ecotoxicity of Polycyclic Aromatic Hydrocarbons in Relation to Soil Sorption, Lipophilicity, and Water Solubility,Environ. Technol. 36:2429-2435.

Tran, V. T., T. P. Q. Bui, D. N. Trinh, T. T. H. Van, and G. B. Long. 2016. Response Surface Methodology Approach for Optimization of $\mathrm{Cu}^{2+}, \mathrm{Ni}^{2+}$ and $\mathrm{Pb}^{2+}$ Adsorption using KOH-Activated Carbon from Banana Peel. Surfaces and Interfaces. 3:1-9.

Wang, J., and S. Kaskel. 2012. KOH Activation of Carbon-Based Materials for Energy Storage. J. Mater. Chem. 22:23710-23725.

Yansya, R. 2013. Sintesis Adsorben Biomassa Alga Tetraselmis sp dengan Pelapisan Silika Magnetit untuk Adsorpsi Ion Pb(II) dan Cu(II). Skripsi. Jurusan Kimia, Fakultas Matematika dan Ilmu Pengetahuan Alam, Universitas Lampung. 